\title{
Peningkatan Kemampuan Berhitung Permulaan Anak Usia Dini Melalui Pengembangan Media Pembelajaran Pohon Angka
}

\author{
Komang Ayu Febiola ${ }^{1 *}$ iD \\ ${ }^{I}$ Prodi Pendidikan Guru Pendidikan Anak Usia Dini, Universitas Pendidikan Ganesha, Singaraja, Indonesia \\ *Corresponding author: Ayufebyola05@gmail.com
}

\begin{abstract}
Permasalahan yang terdapat pada penelitian ini merupakan kurangnya media pembelajaran yang interaktif saat pembelajaran karena terlihat pada saat observasi yang dilalukan terdapat anak yang masih kurang dalam berhitung, anak bingung mencocokkan lambang bilangan dengan angka, anak masih ragu untuk membilang sesuai dengan urutan angka 1-20 dengan benar, keterbatasan media pembelajaran yang mudah membuat anak merasa bosan dalam berhitung permulaan sehingga pasrtisipasi anak masih tergolong sangat rendah. Penelitian ini menggunakan penelitian pengembangan yang bertujuan untuk (1). Merancang media pembelajaran pohon angka untuk meningkatkan kemampuan berhitung permulaan pada anak TK kelompok B, (2). Memahami tingkat kelayakan pada pengguna media pembelajaran pohon angka dari ahli media pembelajaran dan ahli materi, serta mendapat respon pengguna produk yaitu guru kelompok B. Pada penelitian pengembangan ini menggunakan model ADDIE yang terdiri dari beberapa tahap yaitu, Analysis, Design, Development, Implementation, dan Evaluation. Penelitian ini melibatkan ahli materi dan ahli media pembelajaran sebagai validator. Subyek pada penelitian ini adalah guru kelompok B.. Hasil yang sudah diujicobakan terhadap ahli materi mendapatkan persentase skor $82,50 \%$ yang termasuk dalam kategori sangat baik dengan keterangan sangat layak. Hasil yang didapatkan pada ahli media pembelajaran mendapatkan persentase skor $90,00 \%$ yang termasuk dalam kategori sangat baik. Hasil respon pengguna produk yaitu dari 6 orang guru kelompok B dengan persentase skor $88,50 \%$ dengan keterangan sangat baik. Jadi penggunaan media pembelajaran pohon angka berdampak terhadap kemampuan berhitung permulaan anak, penelitian ini dapat menambah wawasan guru mengenai media pembelajaran pohon angka yang dapat digunakan disekolah.
\end{abstract}

Keywords: Media, Pohon Angka, Berhitung Permulaan

\section{Abstract}

The problem in this research is the lack of interactive learning media when teaching children to count beginning because it is seen when observations are made in group B children the child's understanding of counting, children are confused in matching the symbol of numbers with numbers, children are still hesitant to say in accordance with the order number 1-20 correctly, the limitations of learning media easily make children feel bored when learning especially counting early on so that the participation of children in learning in class is still very low. This study uses development research aimed at (1). Designing a number tree learning media to improve the initial numeracy ability in group B kindergarten children, (2). Understanding the level of feasibility of the number tree learning media users from learning media experts and material experts, as well as getting product user responses, namely group B teachers. In this development research using ADDIE models consisting of several stages namely, Analysis, Design, Development, Implementation, and Evaluation. This research involves material experts and instructional media experts as validators. The subjects in this study were group B teachers. The results that have been tested on material experts get a percentage of scores of $82.50 \%$ which are included in the excellent category with very decent information. The results obtained at learning media experts get a percentage score of $90.00 \%$ which is included in the excellent category with very decent information. The results of product user responses are from the 6 group B teachers with a percentage score of $88.50 \%$ with very good information. Based on the results obtained in the product trial, it was stated that the number tree learning media that had been developed could be used in kindergarten as a learning medium. With the aim to facilitate the teacher in helping the learning process in class.

Keywords: Media, Tree of Numbers, Beginning Counting

$\begin{array}{lll}\text { History: } & \text { Publisher: Undiksha Press } \\ \text { Received } & \text { : 3 Juni } 2020 & \text { Licensed: This work is licensed under } \\ \text { Revised } & \text { : 2 Juli } 2020 & \text { a Creative Commons Attribution 3.0 License } \\ \text { Accepted } & \text { : 20 Juli } 2020 & \end{array}$




\section{Introduction}

Pendidikan anak usia dini merupakan pendidikan untuk mempersiapkan anak untuk memasuki sekolah yang lebih lanjut, dengan memberikan rangsangan pendidikan agar pertumbuhan dan perkembangan anak dapat meningkat sesuai dengan pertumbuhan dan perkembangan. Anak yang membangun pengetahuannya sendiri secara aktif yang berkaitan dengan dunia mereka merupakan salah satu kemampuan kognitif yang dimiliki anak. anak akan mempelajari cara berinteraksi dengan lingkungan sesuai dengan perkembanganya yang berkaitan dengan perkembangannya (Marta, 2017). Pemberian rangsangan diberikan pada anak usia 0-6 tahun, pada tahap ini anak memiliki rasa ingin tahu yang tinggi, dan munculah pertanyaan berupa hal yang belum diketahui anak (Ariyanti, 2016). Kemampuan kognitif merupakan suatu proses berpikir untuk dapat menyelesaikan masalah, dapat berpikir logis, dan mengingat (Basri, 2017). Pemberian dorongan aspek kognitif pada anak dapat menggunakan cara berpikir membandingkan, menggabungkan dan mengingat kejadian yang terjadi (Rozalina, 2018).

Salah satu aspek dalam kognitif adalah berhitung. Berhitung merupakan salah satu pelajaran yang paling utama dan penting diberikan pada anak-anak yang berada pada taman kanak-kanak (Sudarsana, 2017). Mengembangkan dasar pengetahuan pada taman kanakkanak diperlukan suatu permainan yang bisa menarik perhatian anak untuk belajar dan membangun rasa ingin tahu pada anak. Belajar berhitung dapat membangun proses pembelajaran yang menyenangkan sehingga anak akan memiliki kesiapan dan bekal kemampuan berhitung untuk dibawa ke jenjang yang lebih tinggi (Darnis, 2018). Kemampuan berhitung yang dimiliki oleh masing-masing anak yang dibawa dari sejak kecil yang dikembangkan melalui dari lingkungan sekitar anak melalui media permaian yang kreatif dan inovatif untuk dapat menumbuhkan minat anak dalam belajar berhitung (Sagita, 2020).

Suryana (2018) menyatakan bahwa tujuan dari berhitung permulaan secara umum di TK bertujuan agar anak mengetahui dasar-dasar pembelajaran berhitung pada jenjang selanjutnya, sehingga pada saat nanti anak lebih siap mengikuti pembelajaran matematika dan berhitung sangat diperlukan untuk mengembangkan pengetahuan anak tentang angka, bilangan, penjumlahan, dan pengurangan dan mengetahui dasar-dasar berhitung untuk anak usia dini seperti memahami lambang bilangan, mengenalkan lambang bilangan dan anak dapat belajar berhitung dari benda-benda yang kongkrit yang ada disekitar. Susanto (2011) menyatakan karakteristik kemampuan berhitung permulaan sebagai berikut. a). Membilang atau menyebutkan urutan bilangan dari 1-20, b). Membilang (mengenal) konsep bilangan dengan benda-benda sampai 10, c). Membuat urutan bilangan 1-10 dengan benda-benda,d). Menghubungkan atau memasangkan lambang bilangan dengan benda-benda sampai 10 (anak tidak disuruh menulis), e). Membedakan dan membuat dua kumpulan benda yang sama jumlahnya, yang tidak sama lebih banyak dan lebih sedikit, f). Menyebutkan hasil penambahan dan pengurangan dengan benda sampai 10, g). Memperkirakan urutan berikutnya setelah melihat bentuk lebih dari tiga pola yang berurutan. Misalnya merah, putih, dan biru, h). Meniru pola dengan menggunakan berbagai benda.

Sarahaswati, L, (2019) menyebutkan prinsip-prinsip berhitung yaitu 1). Permainan berhitung diberikan secara bertahap, diawali dengan menghitung benda-benda atau pengalaman peristiwa kongkirt yang dialami melalui pengamatan terhadap alam sekitar, 2). Pengetahuan dan keterampilan pada permainan berhitung diberikan secara bertahap menurut tingkat kesukarannya, misalnya dari kongkrit ke abstrak, mudah ke sukar, dan dari sederhana ke yang lebih kompleks, 3). Permainan akan berhasil jika anak diberikan kesempatan untuk berpartisipasi dan dirangsang untuk menyelesaikan masalah-masalahnya sendiri, 4). Permainan berhitung membutuhkan suasana menyenangkan dan memberikan rasa aman serta kebebasan bagi anak. maka dari itu diperlukan alat peraga/media yang sesuai dengan benda 
sebenarnya (tiruan), menarik, kreatif, bervariasi, mudah digunakan dan tidak membahayakan, 5). Bahasa yang digunakan di dalam pengenalan konsep berhitung sebaiknya bahasa yang sederhana dan jika memungkinkan mengambil contoh yang ada di lingkungan sekitar anak, 6). Dalam mengevaluasi hasil dari perkembangan anak harus dimulai dari awal sampai dengan akhir kegiatan.

Tahapan-tahapan berhitung permulaan ada 3 (tiga) tahapan yaitu tahapan konsep, tahapan transisi, dan tahapan lambang. Pertama ada tahapan konsep pada konsep ini anak diberikan pengenalan dengan benda-benda kongkrit dan memberikan pelajaran menarik agar anak tidak bosan, kedua yaitu tahapan transisi. Pada tahap transisi/peralihan ini anak sudah mulai dapat mengenal lambang bilangan dengan menghitung jumlah benda tersebut dan tahap yang terakhir yaitu tahap lambang tahap ini anak sudah dapat menuliskan lambang bilangan tanpa harus dipaksa anak juga dapat menggambarkan jika 7 (tujuh) itu lambang bilangan (Authary, 2016).

Kondisi dengan kenyataan berbeda dengan apa yang diharapkan proses pembelajaran yang kurang menggunakan media pembelajaran yang inovatif, guru masih menggunakan metode ceramah dan hanya menggunakan media papan tulis sehingga munculnya rasa bosan pada saat pembelajaran berlangsung. Berdasarkan pengamatan dan wawancara dengan kepala sekolah dan guru kelompok B DI TK Negeri Pembina Badung yang menjadi tempat penelitian guru seringkali menjumpai anak yang kurang aktif saat pembelajaran, anak juga kurang memahami pembelajaran yang dijelaskan oleh guru, kemampuan berhitung pada anak masih sangat rendah, anak sulit menyebutkan angka 1-20 dengan benar, anak sulit membedakan lambing bilangan dengan bilangan. Hasil observasi ini didukung oleh Safitri (2016) kurangnya kemampuan berhitung permulaan pada anak seperti : (1) anak susah menyebutkan angka 1 sampai 10 dengan benar, (2) pada saat guru memberikan pertanyaan kepada keseluruhan anak dikelas semua akan bias menjawab tetapi jika ditanya satu per satu maka anak tidak bias menjawab. Hasil observasi lainnya didukung oleh Sholihah, Maret'atush., Afifulloh. M., (2019) anak sulit memahami apa yang dijelaskan oleh guru karena pada saat menjelaskan guru hanya memberikan penjelasan tanpa mengenalkan simbo;-simbol angka terlebih dahulu dan penelitian ini didukung juga oleh Amaris., Rakimahwati., Marlina (2018) anak sudah mampu menyebutkan angka 1 sampai 10, tetapi anak merasa kesulitan apabila anak disuruh mencocokkan lambang bilangan dengan bilangan. Jika hal ini dibiarkan guru masih menggunakan media pembelajaran seadanya dan metode ceramah yang akan menimbulkan dampak terhadap kemampuan berhitung permulaan pada anak, maka dampak yang diperoleh anak yaitu munculnya rasa bosan saat pembelajaran, anak kurang memahami pembelajaran, dan minat anak dalam belajar sangat rendah. Maka dari itu solusi yang dapat ditawarkan untuk meningkatkan kemampuan berhitung permulaan pada anak yaitu dengan mengembangkan media pembelajaran pohon angka.

Pembelajaran yang menggunakan media pembelajaran akan menumbuhkan semangat anak dalam belajar. Dampak positif pada peningkatan pembelajaran dapat dirasakan apabila dalam proese pembelajaran menggunakan media atau alat bantu yang menarik dan menyenangkan yang menimbulkan kesenangan dan nuanda pembelajaran dan pengalaman yang baru (Liyana, Astien, 2019). Permainan berhitung dapat membangun proses pembelajaran yang menyenangkan sehingga anak akan memiliki kesiapan dan bekal kemampuan berhitung untuk dibawa ke jenjang yang lebih tinggi (Oktriyani, 2017). Dari berbagai media yang diajarkan menggunakan media pembelajaran edukatif atau alat permaianan edukatif (APE) dapat menumbuhkan minat anak dalam belajar. Menggunakan alat permainan edukatif ini bentuk kegiatan yang dilakukan untuk memperoleh kesenangan dari cara atau media pendidikan yang digunakan dalam kegiatan bermain, yang disadari atau tidak, memiliki muatan pendidikan yang dapat bermanfaat dalam mengembangkan peserta didik. Artinya permainan edukatif merupakan sebuah bentuk kegiatan mendidik yang 
dilakukan dengan menggunakan cara atau media permainan yang bersifat mendidik (Hasnida, 2014).

Media pembelajaran merupakan suatu alat peraga yang dibawa oleh guru yang berupa fisik maupun teknis dalam membantu proses pembelajaran yang dapat mempermudah guru dalam menyampaikan materi pelajaran kepada siswa sehingga tujuan dari pembelajaran tercapai dengan baik (Tafonao, 2018). Sedangkan menurut Aqib (2013) media pembelajaran merupakan segala suatu cara yang dapat digunakan untuk menyampaikan pesan dalam proses pembelajaran yang dapat merangsang siswa untuk mencapai tujuan dari proses pembelajaran. Asyhari (2016) menyatakan media pembelajaran merupakan bagian yang terpenting dalam sistem pembelajaran, pemilihian media yang tepat akan menunjukkan proses pembelajaran yang ingin dicapai oleh guru serta dapat mendorong kemauan siswa untuk belajar dengan adanya media yang menarik dan inovatif.

Dengan adanya pengembangan media pembelajaran pohon angka guru lebih mudah menjelaskan materi yang ingin disampaikan dan anak akan mudah mengerti pada saat pembelajaran. Noge, M.D. (2019) menyatakan media pohon angka merupakan salah satu media pembelajaran yang dapat mendorong anak atau menstimulus anak dalam mengenal lambang bilangan angka dengan tepat. Media pohon angka merupakan sebuah media sekaligus menjadi alat bermain bagi anak untuk dapat mengetahui banyak hal (Rahayu, Lestari \& Cahaya, 2019). Anak akan dapat mengenal dan memperoleh pengalaman baru mengenai benda-benda tertentu seperti nama-nama benda, jumlah, warna, membaca, berhitung, menulis dan sebagainya. Sedangkan Budiartini, Desak Putu., Jampel I.N., \& Asril., (2014) menyatakan bahwa media pohon angka adalah satu media suatu media yang dapat digunakan untuk proses pembelajaran terutama di Taman Kanak-kanak yang merupakan salah satu permainan edukasi untuk berlatih berhitung anak-anak melalui media permainan edukatif. Media ini adalah alat permainan edukasi (APE) untuk kelompok pendidikan anak usia dini (PAUD). Pohon angka juga dapat digunakan untuk melatih kemampuan kognitif anak salah satunnya untuk mengenalkan lambang bilangan dan konsep bilangan.

Media pembelajaran pohon angka memiliki beberapa manfaat seperti yang dikemukan oleh Nurrahmadani, Anizar Ahmad (2017) sebagai berikut, 1). Mengenalkan konsep bilangan yaitu dengan cara berpikir anak bersifat memusat dan masih kaku, perlunya media yang dan metode dalam pembelajaran. Dengan adanya konsep bilangan di dalam media pohon angka tersebut, anak lebih bersemangat dan menyenangkan dalam mengenal lambang bilangan, 2). Mengenal bentuk dan warna benda yaitu dengan adanya mengenalan warna, bentuk dan simbol pada anak, anak akan mengerti dasar-dasar mengelompokkan sesuatu dasar satu dimensi, seperti kesamaan warna, bentuk, dan ukuran, 3). Meningkatkan kemampuan berpikir yaitu anak akan melatih sel-sel otaknya untuk mengembangkan kemampuan berpikir saat anak melepas dan memasangkan lambang bilangan, anak memiliki kepekaan terhadap angka, senang melihat lambang bilangan, cepat menguasai simbol bilangan dan pembilangan, mengidentifikasi dengan baik angka pada uang serta mampu membilang dengan cepat.

Adapun langkah-langkah dalam bermain media pembelajaran pohon angka sebagai berikut, 1). Guru mempersiapkan media pembelajaran berupa pohon angka, 2). Pada saat pembelajaran guru meletakkan media pohon angka di depan kelas agar terlihat oleh anak, 3). Guru akan memberikan contoh aturan bermain terlebih dahulu kepada anak, 4). Setelah memberikan aturan kepada anak, kemudian guru menunjuk anak untuk maju kedepan, anak menghitung angka pada gambar buah sesuai dengan bilangan yang disuruh oleh guru, 5). Anak memasangkan benda gambar buah pada lambang bilangan sesuai angka yang diperintahkan guru.

Penelitian ini bertujuan untuk mengetahui peningkatakan tentang kemampuan berhitung permulaan dengan pengembangan media pembelajaran pohon angka pada anak kelompok B TK Negeri Pembina Badung Tahun Pelajaran 2019/2020 secara umum hasil 
penelitian yang dilakukan dapat bermanfaat untuk sekolah khususnya pada TK Kelompok B sehingga dapat memperluas pengetahuan guru tentang media pembelajaran pohon angka untuk meningkatkan kualitas pembelajaran disekolah

\section{Materials and Methods}

Penelitian pengembangan media pembelajaran ini menggunakan model ADDIE. Pemilihan model ini didasari atas pertimbangan bahwa model ini mudah untuk dipahami, selain itu juga model ini dikembangkan secara otomatis dan sistematis. Tahapan penelitian pengembangan pada model ADDIE yaitu sebagai berikut: (1) Analis (Analysis), (2) Desain/perancangan (Design), (3) Pengembangan (Development), (4) Implementasi (Implementation) dan (5) Evaluasi (Evaluation) (Pribadi, 2017). Populasi pada penelitian ini adalah keseluruhan guru kelompok B TK Negeri Pembina Badung dengan jumlah 6 orang guru sebagai pengguna media pembelajaran, 2 ahli materi pembelajaran yaitu dosen Universitas Pendidikan Ganesha dan 1 ahli media pembelajaran yaitu kepala sekolah TK Negeri Pembina Badung. Metode yang digunakan pada penelitian ini yaitu menggunakan metode non-test dengan memberikan kuesioner yang terdiri dari 3 aspek yaitu materi, desain media pembelajaran dan manfaat yang diberikan kepada guru kelompok B, ahli media pembelajaran dan ahli materi dengan menggunakan metode analisis yaitu analisis skala likert.

Pada tahap awal dalam penelitian ini merupakan observasi tahap untuk mengumpulkan informasi, pengumpulan informasi pada tahap ini dilaksanakan dengan cara observasi ke lapangan (TK). Pelaksanaan observasi ini dapat dijadikan acuan untuk membuat suatu produk yang sesuai dengan kebutuhan dilapangan. Pada hal ini produk yang ingin dibuat dan dikembangkan yaitu produk berupa media pembelajaran pohon angka untuk meningkatkan kemampuan berhitung permulaan pada anak kelompok B di TK Negeri Pembina Badung. Tahap selanjutnya yaitu tahap desain proses pembuatan media pohon angka, dibutuhkan perlengkapan untuk membuat media pohon angka, seperti sterofom, penggaris, gunting, cuter, spidol, kertas lipat dan push pins. Selanjutnya merupakan tahap pengembangan, tahap pengembangan merupakan tahap merealisasikan media pohon angka yang sudah didesain agar menjadi produk yang nyata. Hasil pada produk ini merupakan produk yang siap diuji cobakan pada sekolah.

Dalam tahapan pembuatan media pohon angka kegiatan yang dilakukan dalam pembuatan yaitu, (1) Menggambar sketsa pohon angka pada sterofom dan membuat sketsa kepingan angka pada kertas karton sesuai dengan desain, (2) Memotong sketsa pohon angka dan kepingan angka sesuai bentuk yang sudah ditentukan, (3) Melapisi kertas karton dengan kertas lipat untuk menempelkan tulisan angka, (4) Merapikan sisi bagian dari media pohon angka dengan menggunakan cutter, (5) Tahap terakhir menempelkan kepingan angka ke media pohon angka menggunakan push pins, (6) Membuat angket validitas produk untuk ahli yaitu tentang desain media, angket yang dibuat untuk ahli desain media terdiri dari aspek desain tampilan fisik, tampilan variasi warna, serta tingkat kemudahan penggunaan produk, (7) Membuat angket validitas produk untuk ahli materi mengenai materi tentang media pohon angka yang terdiri dari, aspek isi dari materi, kemudahan dalam memahami materi yang disajikan dalam media pohon angka serta apakah sesuai dengan kompetensi pembelajaran pada TK, (8) Membuat angket validitas produk untuk responden yaitu guru, angket ini dibuat untuk mengetahui respon guru mengenai penilaian media pohon angka yang sudah dibuat. Aspek yang ada pada angket ini berupa respon terhadap media pembelajaran dan tingkat kemudahan dalam penggunaan media pohon angka, (9) Validasi produk oleh validator yaitu menjelaskan tentang proses ini dilaksanakan validasi pada produk media pohon angka yang telah dibuat terhadap ahli media (kepala sekolah) dan ahli materi (dosen), validasi ini menggunakan angket yang sudah dibuat pada tahap sebelumnya. Setelah mendapatkan masukan dari para ahli dan divalidasi, maka akan diketahui kekurangan dan kelemahan dari 
media pohon angka dengan cara memperbaiki produk yang dibuat. Produk yang sudah direvisi dan mendapatkan predikat baik, maka produk yang dibuat tersebut dilanjutkan ke tahap implementasi.

Selanjutnya merupakan tahapan Tahap implementasi ini dilakukan kepada guru kelompok B sebagai praktisi media pembelajaran pohon angka. Guru diberikan angket penilaian yang sudah disusun pada tahap sebelumnya. Jika pada tahap uji coba yang dilakukan oleh guru mendapat tanggapan yang baik untuk digunakan dan dapat meningkatkan proses pembelajaran di TK, maka produk sudah dapat dikatakan layak untuk digunakan. Tetapi komentar dan saran dari guru pada tahap ini dapat menjadi pertimbangan untuk dilakukan revisi pada media pohon angka sehingga produk yang dihasilkan lebih baik lagi. Selanjutnya jika kuesioner untuk ahli media pembelajaran, ahli materi dan enam guru kelompok B sudah siap maka selanjutnya masing-masing ahli akan memberikan penilaian menggunakan penilaian skala likert pada Tabel 1.

Tabel 1. Penilaian skala likert.

\begin{tabular}{cc}
\hline Skor & Keterangan \\
\hline 5 & Sangat setuju \\
\hline 4 & Setuju \\
\hline 3 & Cukup baik \\
\hline 2 & Kurang setuju \\
\hline 1 & Sangat tidak setuju \\
\hline
\end{tabular}

Sumber : (Arikunto, 2013) dengan modifikasi peneliti

Untuk hasil persentase skor rata-rata yang diperoleh dari masing-masing ahli media pembelajaran, ahli materi dan enam guru kelompok B kemudian dirata-ratakan kembali untuk mendapatkan satu nilai yang dapat mewakili responden, dapat dilakukan dengan cara menjumlahkan keseluruhan nilai dari responden kemudian membaginya dengan jumlah responden. Kriteria ini merupakan pengambilan keputusan yang digunakan dalam penelitian ini menggunakan konversi tingkat pencapaian dengan skala lima yaitu indicator keputusan skor kuesioner dapat dilihat pada Tabel 2.

Tabel 2. Skala Lima

\begin{tabular}{ccc}
\hline Tingkat Pencapaian (\%) & Kualifikasi & Keterangan \\
\hline $81-100 \%$ & Sangat Baik & Sangat layak/ sangat valid \\
\hline $61-80 \%$ & Baik & Layak/ Valid \\
\hline $41-60 \%$ & Cukup Baik & Kurang layak/ kurang valid \\
\hline $21-40 \%$ & Kurang Baik & Tidak layak/ tidak valid \\
\hline$<20 \%$ & Sangat Kurang Baik & Sangat tidak layak/ sangat tidak valid \\
\hline
\end{tabular}

Sumber : (Arikunto, 2015) dengan modifikasi peneliti

Apabila persentase nilai dari validator kuesioner memenuhi kualifikasi baik/layak, maka tahap yang terakhir merupakan tahap evaluasi pada bagian tahap evaluasi produk dinilai keseluruhan untuk dapat mengetahui hasil akhir dari produk yang dikembangkan setelah diterapkan pada subyek pengguna. Hal selanjutnya terkait dengan kelemahan dan kekurangan yang ada pada produk tersebut yang nantinya dapat diperbaiki lagi sehingga produk yang dikembangkan tersebut memenuhi kriteria kelayakan yang telah ditentukan oleh ahli media pembelajaran.

\section{Results and Discussion}

Pengembangan produk pada penelitian ini yaitu pengembangan media pembelajaran pohon angka yang dapat berfungsi sebagai alat bantu mengajar berhitung permulaan 
khususnya pada anak kelompok B di Taman Kanak-kanak. Pengembangan media pembelajaran pohon angka juga merupakan alat permainan edukatif (APE) yang dapat mempermudah guru untuk menyampaikan pembelajaran berhitung pada saat belajar. Selanjutnya ketika media pembelajaran pohon angka sudah diuji coba oleh validator ahli materi, ahli media pembelajaran dan enam guru kelompok B maka hasil yang didapat dari masing-masing validator dapat dijabarkan dalam tabel hasil uji kelayakan media pembelajaran dapat dilihat pada Tabel 3.

Tabel 3. Uji Kelayakan Media Pembelajaran

\begin{tabular}{ccl}
\hline Responden & Persentase & Keterangan \\
\hline Ahli Materi & $82,50 \%$ & Sangat layak \\
Ahli Media Pembelajaran & $90,00 \%$ & Sangat layak \\
Guru Kelompok B & $88,50 \%$ & Sangat layak \\
\hline
\end{tabular}

(Sumber Data Hasil Penelitian)

Pengembangan media pembelajaran pohon angka ini melalui lima tahap yaitu, tahap analisis, tahap desain, tahap pengembangan, tahap implementasi dan tahap evaluasi. Keseluruhan tahapan ini sudah dilaksanakan sesuai dengan penelitian yang sudah dirancang sebelumnya dan uji coba yang dilakukan oleh validator ahli materi, ahli media pembelajaran dan enam guru kelompok B menggunakan alat ukur yang berupa kuesioner tertutup yang sudah divalidasi oleh penilaian dari validator agar dapat menentukan hasil kelayakan dari kuesioner sebagai alat ukur (Sugiyono, 2017). Hasil validasi dari ahli materi mengenai kesesuaian materi yang disampaikan, konsep pemahaman tentang media pembelajaran pohon angka, kelayakan media pembelajaran pohon angka saat digunakan dalam proses pembelajaran, kebermanfaatan bagi anak dan bagi guru. Maka, dengan menggunakan kuesioner sebagai alat ukur pengembangan media pembelajaran pohon angka dapat divalidasi oleh ahli materi. Jadi berdasarkan hasil dari validator dari menggunakan dua ahli materi yang menilai menggunakan kuesioner yang memperoleh skor 5 (sangat setuju), skor 4 (setuju) dan 3 (cukup baik). Jadi berdasarkan hasil yang diperoleh dari dua ahli materi termasuk dalam kriteria yang sangat baik dengan persentase yang didapat $82,50 \%$ dan sangat layak untuk digunakan pada pembelajaran di TK.

Hasil validasi selanjutnya yaitu ahli media pembelajaran menggunakan kuesioner yang mengenai desain tampilan dari media pembelajaran pohon angka, fleksibelitas dari media pohon angka, kelayakgunaan media pembelajaran pohon angka, bahan yang digunakan pada pembuatan media pohon angka dan pemilihan warna yang tepat agar terlihat menarik. Dan dari hasil yang diperoleh dari validator ahli media pembelajaran yang menggunakan kepala sekolah TK maka tersebar skor pada kuesioner yaitu skor 5 (sangat setuju) dan 4 (setuju), dengan memperoleh hasil persentase yang didapat yaitu 90,00\% dan sangat layak digunakan untuk media pembelajaran di TK. Selanjutnya hasil validasi yang dilakukan oleh enam guru kelompok B, dengan menggunakan kuesioner. Berdasrkan hasil uji coba yang dilakukan oleh enam guru kelompok B yang mengenai isi materi yang dapat disampaikan dari media pembelajaran pohon angka, kelengkapan angka yang dibuat pada media pembelajaran pohon angka, manfaat bagi anak dan bagi guru, maka hasil penilaian yang tersebar pada skor 5 (sangat setuju), 4 (Setuju) dan 3 (cukup baik), dilihat dari hasil kuesioner dari enam guru kelompok B mendapat nilai dengan persentase $88,50 \%$ yang termasuk dalam kualifikasi sangat layak.

Kemampuan berhitung permulaan merupakan anak dapat menyebutkan urutan bilangan sampai 10, kegiatan berhitung permulaan juga sering disebut kegiatan menyebut urutan bilangan dimulai dari usia 4 tahun anak bisa mengurutkan angka 1-10 dan usia 5-6 tahun anak mampu menyebutkan bilangan 1-20 (Yuliani, Dwi. Antara. P.A., 2017). Adapun 
karakteristik berhitung permulaan pada anak usia dini yaitu anak mampu menyebutkan angka 1-20, anak mampu mengurutkan angka 1-20, anak mampu membilang banyak benda 1-20, anak mampu membilang 1-20 dengan menunjuk benda, anak mampu menunjukkan lambang bilangan, anak mampu mencocokan atau memasangkan lambang bilangan dengan bendabenda atau sebaliknya, anak mampu menunjukkan 2 kumpulan benda dengan untuk membedakan jumlah benda banyak atau sedikit.

Berdasarkan hasil yang diperoleh dalam masing-masing validator diatas dapat disimpulkan bahwa dengan dikembangkannya media pembelajaran pohon angka layak untuk digunakan sebagai media pembelajaran yang edukatif, inovatif dan dapat membantu guru dengan mudah menyampaikan pembelajaran khususnya berhitung permulaan pada anak kelompok B, penelitian ini juga relevan dengan penelitian lainnya yang menggunakan media pohon angka seperti penelitian Afsari, dan Aina (2019) yaitu dengan menggunakan media pohon angka dapat meningkatkan kemampuan berhitung anak usia dini sedangkan Amirdyasari (2017) telah membuktikan kemampuan berhitung permulaan anak usia dini meningkat setelah menggunakan media pembelajaran pohon hitung; dan Marfuah (2017) pada penelitian ini upaya meningkatkan kemampuan mengenal lambing bilangan kepada anak usia dini memang efektif menggunakan media pembelajaran pohon angka. Sesuai hasil penelitian diatas maka pengembangan media pembelajaran pohon angka pada penelitian ini memiliki keunggulan yang dapat meningkatkan kemampuan berhitung permulaan pada anak usia dini.

\section{Conclusion}

Dapat disimpulkan bahwa melalui pengembangan media pembelajaran pohon angka dapat meningkatkan kemampuan berhitung permulaan pada anak khusunya kelompok B pada anak TK Negeri Pembina Badung Tahun Pelajaran 2019/2020. Dengan pengembangan media pembelajaran pohon angka penelitian ini memiliki keunggulan yang dapat meningkatkan berhitung permulaan pada anak yaitu dapat menyusun angka dengan benar, dapat menyebutkan angka 1-20, dapat membedakan angka 1-20, dan dapat mencocokkan angka dengan lambang bilangan dengan benar. Berdasarkan data temuan yang didapat diharapkan guru dapat mengembangkan media pembelajaran yang lebih inovatif agar lebih bisa meningkatkan kemampuan berhitung permulaan pada anak, meningkatkan semangat belajar pada anak dan tidak timbulnya rasa bosan saat pembelajaran. Kepada kepala sekolah hendaknya pengembangan media pembelajaran pohon angka mampu menjadi media pembelajaran yang dapat diterapkan disekolah untuk dapat mengembangkan kualitas pembelajaran. Disarankan bagi peneliti lain hendaknya dapat mengemangkan media pembelajaran yang telah dibuat dari berbagai aspek, baik dari materi, desain, pembuatan dan lain sebagainya sehingga media pembelajaran dalam dunia pendidikan lebih bervariasi, inovatif dan edukatif.

\section{References}

Afsari, Y. \& A. M. (2019). Peningkatan Kemampuan Berhitung Anak Usia Dini Melalui Permainan Pohon Angka Di RA Muslim Kecamatan Bandung Kulon Kota Bnadung. $\begin{array}{llll}\text { Journal on } & \text { Education, }\end{array}$ http://jonedu.org/indeks.php/joe/article/view/223/189.

Amaris, Della Ulfa., Rakimahwati., \& M. S. (2018). Pengaruh Media Busy Book Terhadap Kemampuan Berhitung Anak Usia Dini Di Taman Kanak-Kanak Fadhilah Amal 3 Padang. Universitas Negeri Padang Jurnal Usia Dini, 4, 10.

Amirdyasari, S. H. (2017).Peningkatan Kemampuan Berhitung Permulaan Anak Kelompok B Melalui Bermain Media Pohon Hitung Di TK Taman Indria Kecamatan Bangorejo 
Kabupaten Banyuwangi Tahun Pelajaran 2016/2017. Skripsi, 53. https://repository.unej.ac.id/bitstream/handle/123456789/82484/SHINTA\%25HARDIK NA\%2520AMIRDYASARI.pdf?sequence $=1$

Aqib, Z. (2013). Mode-Model Media Pembelajaran dan Strategi Pembelajaran Konteksual (Inovatif). Bandung: Yrama Widya.

Arikunto, S. (2013). Dasar-Dasar Evaluasi Pendidikan. Jakarta: Bumi Aksara.

Arikunto, S. (2015). Dasar-Dasar Evaluasi Pendidikan. Jakarta: Bumi Aksara.

Ariyanti, T. (2016). Pentingnya Pendidikan Anak Usia Dini Bagi Tumbuh Kembang Anak The Importance Of Childhood Education For Child Development. Jurnal Dinamika Pendidikan Dasar, 8(1), 58. http://jurnalnasional.ump.ac.id/index.php/Dinamika/article/view/943/881

Asyhari, A. \& H. S. (2016). Pengembangan Media Pembelajaran Berupa Buletin Dalam Bentuk Buku Saku Untuk Pembelajaran IPA Terpadu. Jurnal Ilmiah Pendidikan Fisika Al-Briruni., $\quad 5 . \quad$ http://ejournal.radenintan.ac.id/index.php/albiruni/article/download/100/91\%0

Authary, N. (2016). Number sense anak usia dini: suatu investigasi pada aritmetika tahap awal. 1(2), 4. http://103.107.187.25/index.php/bunayya/article/download/2031/1503

Basri, H. (2017). Kemampuan Kognitif Dalam Meningkatkan Efektivitas Pembelajaran Ilmu Sosial Bagi Siswa Sekolah Dasar. Jurnal Penelitian Pendidikan, 3. https://ejournal.upi.edu/index.php/JER/article/download/11054/6741\%0A\%0A

Budiartini, Desak Putu., Jampel I.N., \& Asril., N. . (2014). Penerapan Metode Pemberian Tugas Berbantuan Media Pohon Angka Untuk Meningkatkan Kemampuan Mengenal Lambang Bilangan. E-Journal PG-PAUD Universitas Pendidikan Ganesha Jurusan Pendidikan Anak Usia Dini, https://ejournal.undiksha.ac.id/index.php/JJPAUD/article/download/3529/2848\%0A\%0 A

Darnis, S. (2018). Aplikasi Montessori Dalam Pembelajaran Membaca, Menulis Dan Berhitung Tingkat Permulaan Bagi Anak Usia Dini. Jurnal Caksana, 1(1), 3. http://trilogi.ac.id/journal/ks/index.php/PAUD/article/download/3/1\%0A\%0A

Hasnida. (2014). Media Pembelajaran Kreatif. Jakarta Timur: PT Luxima Metro Media.

Liyana, Astien, M. K. (2019). Speaking Pyramid Sebagai Media Pembelajaran Kosa Kata Bahasa Inggris Anak Usia 5-6 Tahun. Jurnal Pendidikan Anak Usia Dini, 3(1), 227. https://obsesi.or.id/index.php/obsesi/article/download/178/114\%0A\%0A

Marfuah, F. \& H. H. S. (2017). Upaya Meningkatkan Kemampuan Mengenal Bilangan Pada Anak Usia Dini Menggunakan Media Pohon Angka Di Kelompok B TK Pelangi $\begin{array}{lllll}\text { Aisyiyah Jumantoro. Jurnal } & \text { AUDI, }\end{array}$ http://ejurnal.unisri.ac.id/index.php/jpaud/article/download/1679/1483

Marta, R. (2017). Penanganan Kognitif Down Syndrome Melalui Metode Puzzle Pada Anak Usia Dini. Jurnal Pendidikan Anak Usia Dini, 1(1), 34. https://obsesi.or.id/index.php/obsesi/articl/download/29/27\%0A\%0A

Noge, M.D., M. M. \& N. E. . (2019). Pengembangan Media Pohon Angka Untuk Aspek Kemampuan Berbahasa Pada Anak Usia 5-6 Tahun Di TKK Negeri Bunga Bangsa 
Tude Kecamatan Jerebu Kabupaten Ngada. Jurnal Edukasi Anak Usia Dini, 5(2), 71. https://www.researchgate.net/publication/338860684_Pengembangan_Media_Pohon_A ngka_Untuk_Aspek_Kemampuan_berbahasa_pada_anak_usia_5sampai6_tahun_di_TK K_Negeri_Bunga_Bangsa_Tude_Kecamatan_Jerebuu_Kabupaten_Ngada.pdf?origin=p ublication_detail

Nurrahmadani, Anizar Ahmad, \& Y. (2017). Memperkenalkan Bilangan Untuk Anak Usia Dini Dengan Menggunakan Media Pohon Angka Di TK Darurrahman Kota Banda Aceh. Jurnal Ilmiah Mahasiswa Pendidikan Guru Anak Usia Dini, 2(1), 71. http://www.jim.unysiah.ac.id/paud/article/download/5798/4500

Oktriyani, N. (2017). Peningkatan Kemampuan Berhitung Anak Usia Dini Melalui Permainan Lingkaran Angka Di Taman Kanak-Kanak Qatrinada Kecamatan Kotto Tangah Padang. Universitas Negeri Padang: Jurnal Pendidikan Anak Usia Dini, 1, 86. https://journal.unilak.ac.id/index.php/paud-lectura/article/view/510/376

Pribadi, B. (2017). Media dan Teknologi dalam Pembelajaran. Jakarta: Kencana.

Rahayu, Made Ayu Nadi, L. P. I. C. I. M. . (2019). Implementasi Alat Permainan Edukatif Pohon Angka Dalam Meningkatkan Kemampuan Mengenal dan Lambang Bilangan. Media Edukasi, $3(1), \quad 29$. https://jurnal.undhirabali.ac.id/index.php/jmk/article/download/730/643 \%0A\%0A

Rozalina, L. (2018). Pengembangan Aspek Kognitf Anak Usia Dini Dengan Menggunakan Permainan Outdoor Di PAUD Harapan Ananda Kota Bengkulu. Skripsi, 4. http://repository.iainbengkulu.ac.id/2787/1/skripsi lisa roza lina.pdf

Safitri, E. (2016). Upaya Meningkatkan Kemampuan Berhitung Melalui Permainan Congklak Di Taman Kanak-Kanak Nurul Iman Bandar Lampung. Universitas Lampung. Jurnal PAUD, 6. http://digilib.unila.ac.id/23780/3/Skripsi Tanpa Bab Pembahasan.pdf\%0A\%0A

Sagita, E. (2020). Pengaruh Bermain Kereta Angka Terhadap Kemampuan Berhitung Pada $\begin{array}{llllll}\text { Anak Di } & \text { TK } & \text { Babatan } & \text { Seluma. } & \text { Skripsi, } & 7 .\end{array}$ http://repository.iainbengkulu.ac.id/4506/1/Skripsi Eli Sagita.pdf

Sarahaswati, L, H. (2019). Mengenal Keaksaraan Di Taman Kanak-Kanak. Bandung : Pusat Pengembangan Dan Pemberdayaan Pendidikan Dan Tenaga Kependidikan Taman Kanak-Kanak Dan Pendidikan Luar Biasa.

Sholihah, Maret'atush., Afifulloh. M., L. Y. F. (2019). Penerapan Metode Bermain Flashcard Untuk Meningkatkan Kemampuan Berhitung Anak Kelompom B Di RA Amin Pakis Malang". Universitas Islam Malang. Jurnal Ilmiah Pendidikan Islam Anak Usia Dini., 1, 66. http://riset.unisma.ac.id/index.php/jd/article/viewFile/3217/2866\%0A\%0A

Sudarsana, K. (2017). Membentuk Karakter Anak Sebagai Generasi Penerus Bangsa Melalui Pendidikan Anak Usia Dini. Membentuk Karakter Anak, 1(1), 42. http://jurnal.stahnmpukuturan.ac.id/index.php/.Purwadita/article/download/8/7

Sugiyono. (2017). Penelitian Pendidikan (Pendekatan Kuantitatif, Kualitatif dan R\&D). Bandung: Alphabeta.

Suryana, D. (2018). Pendidikan Anak Usia Dini Stimulasi \& Aspek Perkembangan Anak. Jakarta: Prenadamedia Group.

Susanto, A. (2011). Perkembangan Anak Usia dini. Jakarta: Kencana. 
Tafonao, T. (2018). Peranan Media Pembelajaran Dalam Meningkatkan Minat Belajar $\begin{array}{llll}\text { Mahasiswa. Jurnal Komunikasi Pendidikan, } & 2(2),\end{array}$ http://journal.univetbantara.ac.id/index.php/komdik/article/download/113/101

Yuliani, Dwi. Antara. P.A., M. . (2017). Pengaruh Video Pembelajaran Terhadap Kemampuan Berhitung Permulaan Anak Kelompok B Di Taman Kanak-Kanak. EJournal Pendidikan Anak Usia Dini, 5(1). https://ejournal.undiksha.ac.id/index.php/jjpaud/article/download/11309/12956. 